\title{
Molecular diagnosis of Toxoplasma gondii infection in Libya
}

Aisha Gashout ${ }^{1}$, Ahmad Amro ${ }^{2 *}$, Mabruk Erhuma ${ }^{3}$, Hamida Al-Dwibe ${ }^{4}$, Eanas Elmaihub ${ }^{5}$, Hamouda Babba ${ }^{6}$, Nabil Nattah ${ }^{7}$ and Abdalhafid Abudher $^{8}$

\begin{abstract}
Background: Toxoplasma gondii infections are prevalent in humans and animals throughout Libya. Current diagnosis is based on detection of Toxoplasma-specific lgM and IgG. In this study, we established and optimized a diagnostic PCR assay for molecular diagnosis of T. gondii in Libya.

Methods: From January to December, 2010, 177 blood and serum samples were collected from suspected patients. This includes: 140 women who have had spontaneous abortions, 26 HIV-positive patients, nine patients with leukemia and lymphoma, and two infants with ocular infection. Samples were screened for anti-Toxoplasma IgG and IgM antibodies before DNA extraction. The surface antigen gene 2 (SAG2) was targeted in a semi-nested PCR to amplify a $999 \mathrm{bp}$ and a $614 \mathrm{bp}$ fragment in the first and the second run respectively.

Results: A total of 54/140 (38.5\%) women who have had spontaneous abortions, 23/26 (88 \%) HIV patients, 6/9 (66.6 \%) of the leukaemia and lymphoma patients, and one child with ocular infection were seropositive for anti-Toxoplasma lgG and/or IgM. Genomic DNA was extracted from 38 selected seropositive samples. The PCR was sensitive enough to detect DNA concentration of $12 \mathrm{ng} / \mu \mathrm{L}$. PCR analysis was performed for 38 selected seropositive patients (16 women who have had spontaneous abortions, 15 positive HIV patients, six leukaemia patients and one child with ocular infection). Our designed primers were successfully amplified in 22/38 (57.9\%) samples; 5/12 (35.7\%) from serum and 17/26 (65.8 \%) from whole blood samples. All PCR positive samples were lgG-positive except two samples which were $\operatorname{lgM}$ and $\operatorname{lgG} \&$ IgM-positive serum samples respectively. The semi-nested PCR confirmed five more samples. These included two leukaemia and two HIV-positive whole blood samples and one serum sample from an aborted woman.

Conclusion: The ability of PCR to diagnose active toxoplasmosis is needed in immunocompromised patients and congenital toxoplasmosis cases, especially when serological techniques fail. For the first time in Libya, we established and optimized semi-nested PCR of SAG2 gene. The developed PCR method was able to detect as little as $12 \mathrm{ng} / \mathrm{\mu L}$ of T. gondii DNA and was useful to diagnose the diseases in women who have had spontaneous abortions, HIV-positive patients, patients with leukemia and lymphoma, and infants with ocular infection.
\end{abstract}

Keywords: Libya, Toxoplasma, PCR, Semi nested PCR, IgM, IgG, ELISA

\section{Background}

Toxoplasma gondii infections are prevalent in humans and animals worldwide. It has been estimated that onethird of the world population has been exposed to this parasite $[1,2]$. The infection is acquired by ingesting tissue cysts from undercooked or raw meat, consuming food or

\footnotetext{
* Correspondence: ahmadymm@hotmail.com

${ }^{2}$ Faculty of Pharmacy, Al-Quds University, Main Campus, Abu Dis, P.O. Box

5100, Jerusalem, Palestine

Full list of author information is available at the end of the article
}

drink contaminated with oocysts shed by felids, or by accidentally ingesting oocysts from the environment [3].

Although the course of the primary infection is usually subclinical and the vast majority of infected human populations remain asymptomatic, the infection can cause significant morbidity and mortality in certain groups. This includes encephalitis, chorioretinitis, congenital infection and neonatal mortality [4]. Transmission to the fetus occurs in women who acquire their primary infection during gestation and can result in visual and hearing loss, mental and psychomotor retardation, seizures, hematological 
abnormalities, hepatosplenomegaly, or death [5]. The global annual incidence of congenital toxoplasmosis was estimated to be 190,100 cases [6]. High burdens of congenital toxoplasmosis, which where estimated as the highest among all food-borne pathogens [7], were seen in South America and in some Middle Eastern and low-income countries [6]. Moreover, toxoplasmic encephalitis due to reactivation of latent tissue cysts is the most common clinical presentation of toxoplasmosis among persons with AIDS [8-11]. The infection is typically observed in the later stages of human immunodeficiency virus (HIV) infection, when persons become severely immunosuppressed [12, 13]. The incidence of encephalitis in AIDS patients in the general population is directly related to the prevalence of anti- $T$. gondii antibodies [8]. Global seroprevalence of toxoplasmosis is continuingly evolving, subject to regional socioeconomic parameters and population habits. It presents in every country in the world and seropositivity rates range from less than $10 \%$ to over $90 \%$ [14].

In African countries, numerous studies performed in the early 1990s with limited follow-up exists even for the general population of these countries. Recent review by Pappas et al. [14] summarized prevalence rates in Egypt (57.9 \%), Tunisia (58.4\%), Morocco (50.6 \%), Nigeria (20.8\%), Mali (21\%), Benin (3.6 \%), Gabon (71.2\%), Madagascar (83.5\%), and Senegal (40.2 \%). However, limited studies about Libyan toxoplasmosis are available. Seroprevalence of toxoplasmosis among Libyan pregnant women in Benghazi ranges between (44.8 \%) [15], (47.4 \%) [16], and (50 \%) [17], and among non-pregnant Libyan women in Tripoli was estimated to be around (18.14 \%) [18], (43.4 \%) among adult males, and (43.7 \%) of school children [19]. Gashout et al. has shown that (17.6\%) of women who suffered from spontaneous abortion in Tripoli were seropositive for toxoplasmosis [20]. Moreover, prevalence of congenital toxoplasmosis was found to be (44\%) in Tripoli [21]. However, no comprehensive epidemiological analysis was done at the national level in Libya. All previous studies were based on detection of Toxoplasma-specific IgM and IgG. Specific and sensitive molecular diagnostic tools have not yet been implemented and information about disease distribution, parasite life cycle, and combining risk factors is limited.

Due to their high sensitivity and specificity, molecular methods are now recognized as an essential diagnostic tool for maternal and congenital toxoplasmosis [22-30], toxoplasmosis in immunocompromised individuals [31, 32], and ocular toxoplasmosis [33-35]. In most developing countries, including Libya, these methods are not widely used in clinical settings for routine diagnosis and therapeutic management, as they are expensive and time consuming techniques. Current diagnosis of toxoplasmosis in Libya is based on serological methods which have varied sensitivity and specificity depending on the test used [36, 37]. Moreover, serological tests may fail to detect $T$. gondii infection in certain immunocompromised patients due to the fact that the titres of specific anti-Toxoplasma antibodies may fail to rise at the time of diagnosis [38-40]. Hence direct observation of the parasite in biological samples by Polymerase Chain Reaction (PCR) is a major breakthrough for the diagnosis and management of toxoplasmosis [41].

In this study, we described establishment, optimization, and application of diagnostic PCR assay to amplify SAG2 gene of T. gondii from Libyan HIV patients, women who have had spontaneous abortions, leukaemia, and ocular infection patients who were sero-positive for specific Toxoplasma antibodies. To the best of our knowledge, this is the first molecular study of human toxoplasmosis in Libya focusing on establishment of molecular diagnostic technique.

\section{Methods \\ Patients and samples}

A total of 177 blood and serum samples were collected from clinically diagnosed patients during JanuaryDecember 2010. This includes; 140 women who have had spontaneous abortions from out-patient departments, 26 HIV-positive patients from infectious department in Tripoli Central Hospital, nine patients from African Oncology Institute in Sabrata diagnosed with leukemia and lymphoma, and two infants with ocular infection from private Alsharkh Laboratories in Zawia City. Patient's data including, age, sex and location, were collected for epidemiological analysis.

\section{Serologic tests}

Approximately $5 \mathrm{ml}$ of venous blood were collected from each patient. Two $\mathrm{ml}$ were added to plain tube to get serum. The rest was transferred into tube with EDTA for DNA extraction. Serum was separated from the whole blood by centrifugation at $3000 \mathrm{rpm}$ for $5 \mathrm{~min}$ and screened for anti-Toxoplasma IgG and IgM antibodies by using standard ELISA commercial kits (Human Gesellschaft für Biochemica und Diagnostica $\mathrm{GmbH}$, Wiesbaden, Germany) in accordance with the manufacturer's instruction. Moreover, the Architect Toxo IgG and Toxo IgM assays (Abbott Laboratories, Wiesbaden, Germany) was used to confirm ELISA results for a subset of patients to avoid false negatives.

\section{Parasites preparation and genomic DNA extraction}

Reference strain RH (type I) was used as positive control. A stock solution of 1000 tachyzoites/100 $\mu \mathrm{l}$ of PBS was prepared and kept at $-80{ }^{\circ} \mathrm{C}$ until used. The genomic DNA was extracted from the RH T. gondii tachyzoites, blood samples spiked with different concentrations of tachyzoites, 
and from patient's serum and whole blood samples using PureLink $^{\text {TM }}$ Genomic DNA Kit for purification of genomic DNA (Invitrogen) following the manufacturer's instructions. Briefly, cells were lysed and digested with $20 \mu \mathrm{l}$ of Proteinase K, RNase A (50 Mm Tris- $\mathrm{HCl}$, Ph 8.0,10 Mm EDTA) and $200 \mu \mathrm{l}$ of Lysis/Binding Buffer at $55{ }^{\circ} \mathrm{C}$ for $10 \mathrm{~min}$. Absolute ethanol $(200 \mu \mathrm{l})$ was added and the mixture was transferred to the PureLink ${ }^{\mathrm{TM}}$ Spin column in a $2 \mathrm{ml}$ collection tube and centrifuged for $1 \mathrm{~min}$. The columns were washed twice, and the DNA was eluted from the columns with $50 \mu \mathrm{l}$ of elution buffer $(10 \mathrm{mM}$ Tris- $\mathrm{HCl}$, pH 9.0, $0.1 \mathrm{mM}$ EDTA). Spectrophotometric analysis was applied to measure DNA concentration and purity.

\section{Polymerase chain reactions (PCR) and semi-nested PCR}

The surface antigen gene 2 (SAG2), which encode the tachyzoite surface proteins p22 was targeted as described elsewhere [42-45] with modifications. Briefly, a fragment of SAG2 gene (Gene bank: AF 24969) [46] was amplified using two primers; forward (TOXO 29) and reverse (TOXO 1027) to produce a 999 bp fragment (Table 1). Semi-nested PCR was then performed to confirm specificity of first round products by using forward (TOXO 409) and reverse (TOXO 1027) to produce a 614 bp fragment (Table 1). We designed all primers by using online Primer3 Output; http://primer3.ut.ee/.

Conventional PCR was optimized in a $50 \mu \mathrm{L}$ reaction that includes; $5 \mu \mathrm{L}$ of High Fidelity $10 \times$ PCR buffer $(20 \mathrm{mM}$ Tris- $\mathrm{HCl}, \mathrm{pH}$ 7.5, $100 \mathrm{mM} \mathrm{KCl,} 1 \mathrm{mM}$ Dithiothreitol (DTT), 0.1 mM EDTA, 0.5 \% Tween 20, $0.5 \%$ Nonidet P40, $50 \%$ glycerol), $4 \mu \mathrm{L}$ of $(25 \mathrm{mM}) \mathrm{MgCl} 2,5 \mu \mathrm{L}$ of (10 mM) dNTPs, $0.5 \mu \mathrm{L}$ of each $(50 \mathrm{pmol})$ primer, $0.25 \mu \mathrm{L}$ of $(5 \mathrm{U} / \mu \mathrm{l})$ High Fidelity enzyme mix and $10 \mu \mathrm{L}$ of DNA template, and $29.25 \mu \mathrm{L}$ of ultrapure water. The mixture was briefly spun and placed in thermal cycler (GenAmp ${ }^{\oplus}$ PCR system, Applied Biosystem). The reaction conditions were optimized using number of modifications; temperature for primer annealing $\left(58-60{ }^{\circ} \mathrm{C}\right), \mathrm{MgCl} 2$ concentration $(1.5,2$, 3 , $4 \mathrm{mM})$, enzyme mix $(1.1,1.25$ and $2.75 \mathrm{U} / \mu \mathrm{l})$ and primer concentration $(12.516 .5,25,41$, and $45 \mu \mathrm{M})$.

PCR sensitivity was assessed by using serial dilutions of $T$. gondii DNA (RH strain) ranging from 12.5, 25, 50 and $100 \mathrm{ng} / \mu \mathrm{l}$ input per $50 \mu \mathrm{l}$ PCR reaction as described previously [45]. The dilutions were tested by PCR to determine the minimum DNA concentration per reaction that could be detected by this protocol. Moreover, PCR sensitivity was tested by mixing $200 \mu \mathrm{l}$ of whole blood with different concentrations of $T$. gondii tachyzoites of the $\mathrm{RH}$ strain $(10,100$ and 1000 parasites) prior to extraction according to Howe et al. [44].

For semi-nested PCR, we took $5 \mu \mathrm{L}$ of a 1:10 diluted PCR amplicon from the first-round as a template. The protocol for reaction conditions was used as described for first round PCR amplification. Each amplification assay contained a negative control (negative sample for IgG and IgM T. gondii antibodies and/or ultrapure water) and one positive control ( $2 \mu \mathrm{L}$ DNA from RH T. gondii tachyzoites). To guarantee the reliability of the results and detect any possible contamination, all samples were processed in duplicate. The test result was considered positive if the amplified DNA fragment was clearly visible in both samples.

For DNA detection, $5 \mu \mathrm{L}$ of amplicons were analyzed on $1.7 \%$ agarose gel by electrophoresis and visualized by UV light and then photographed under an ultraviolet transluminator. 100 bp plus DNA Ladder (Bioron) was used as a marker. Gel quantification analysis of the bands amplified from blood samples spiked with different concentrations

Table 1 Design of SAG2 PCR and semi-nested PCR analysis

\begin{tabular}{|c|c|c|c|c|}
\hline Primer sequence & \multicolumn{2}{|c|}{$\underline{\text { Design }}$} & $\underline{A n T}$ & $G C \%$ \\
\hline Forward 1 (TOXO 29) & & 29 & & \\
\hline 5'-CTGCTTGCGATTCTGTGTGT-3' & & $\downarrow$ & 60 & 50 \\
\hline Forward 2 (TOXO 409) semi-nested & 409 & 6 & & \\
\hline 5'-AGGTGCGGTCTTGAAAGCTA-3' & 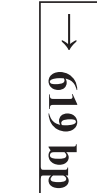 & $\begin{array}{l}\tau \\
\uparrow \\
\uparrow\end{array}$ & 60 & 55 \\
\hline $\begin{array}{l}\text { Reverse (TOXO 1027) } \\
\text { 5'-ACCTGGAGTCACTTCGGAGA-3' }\end{array}$ & $\uparrow$ & $\begin{array}{l}\uparrow \\
\uparrow\end{array}$ & 60 & 55 \\
\hline & & & & \\
\hline
\end{tabular}


of tachyzoites was carried out using ImageJ 1.46r software (National Institutes of Health, Bethesda, MA, USA).

\section{Ethical considerations}

All aspects of the study were revised and approved by the ethics committee of the Libyan National Centre for Disease and Control. Confidentiality was ensured through secure data management and no personal identifiers were in the computer system. Data and samples were labeled with anonymous identification numbers. Informed written consent was obtained from all participants. Since two study participants were infants, parents/guardians provided consent on their behalf. Test results were confidentially disclosed to the subjects following post-test counseling.

\section{Results}

\section{ELISA results for $T$. gondii IgM and IgG antibodies}

One hundred and forty women who have had spontaneous abortions, median age 27 year (range19-41 year) in the first 16 weeks of gestation, were clinically diagnosed and tested for Toxoplasma infection with ELISA. The mean length of pregnancy was 10 weeks (range 1-16 weeks) at the time of abortion and sample collection.

A total of 54/140 (38.5\%) women who have had spontaneous abortions were seropositive; 36 (66.6\%) were positive for IgG antibodies, 12 (22.2 \%) for IgG and IgM antibodies, and $6(11.1 \%)$ for IgM. Moreover, 4 of the IgG-positive women had a history of repeated abortion.

Twenty six HIV positive patients (14 male and 12 female, mean age 37 years old) were tested for T.gondii infection. The HIV-positive patients were considered seropositive if the ELISA result of serum samples had detectable specific Toxoplasma IgG antibodies with titer $\geq 10 \mathrm{IU} / \mathrm{ml}$. A total of 23/26 (88 \%) patients were IgG positive among which 17 (74 \%) had a CD4 cell-count less than 100 cells/ $\mu$ l of blood. CD4 levels in HIV-positive patients with seropositive toxoplasmosis (range, 3 to $273 \mathrm{CD} 4$ cells $/ \mu \mathrm{l}$ of blood) were lower than seronegative patients (range, 345 to $463 \mathrm{CD} 4$ cells $/ \mu$ l of blood).

However, 6/9 (66.6 \%) of the leukaemia and lymphoma patients (five males and four females, mean age 36 year), and one child (male, 4 months) with ocular infection were IgG positive (Table 2). All samples retested with
Architect Toxo IgG and Toxo IgM assays confirmed the ELISA results without any discrepancies.

\section{Genomic DNA Extraction and PCR optimization}

Genomic DNA was extracted from 38 selected seropositive and clinically diagnosed toxoplasmosis patients. The DNA concentration ranged from 16 to $350 \mathrm{ng} / \mu \mathrm{l}$. Optimum PCR cycling parameters were: $94{ }^{\circ} \mathrm{C}$ for $4 \mathrm{~min}$, then 35 cycles at $94{ }^{\circ} \mathrm{C}$ for $1 \mathrm{~min}, 58^{\circ} \mathrm{C}$ for $1 \mathrm{~min}$ and $72{ }^{\circ} \mathrm{C}$ for $2 \mathrm{~min}$. The PCR was completed with $7 \mathrm{~min}$ at $72{ }^{\circ} \mathrm{C}$. Under these conditions, the PCR was sensitive enough to detect DNA concentration of $12 \mathrm{ng} / \mu \mathrm{L}$ of extracted DNA from purified parasite (Fig. 1a). Analytic sensitivity of 10, 100, and 1000 tachyzoites in $200 \mu \mathrm{l}$ whole blood was predicted. We did the PCR for each concentration in triplicate and run a gel for all PCR products together, then we repeated the PCR once again to obtain a gel photo (Fig. 1b). Wile no product was detected from whole blood sample where no parasites were added (Fig. 1b).

\section{PCR amplification of SAG2 locus}

PCR analysis was performed for 38 selected patients (16 women who have had spontaneous abortions, 15 positive HIV patients, six leukaemia patients, and one child with ocular infection). All selected cases were strong seropositive; these included 33 samples that were positive only for IgG antibodies, four samples that were positive for both IgM and IgG antibodies, and one sample were positive for IgM.

Amplification of the SAG2 gene with our designed primers was successful in 22/38 (57.9\%) samples; 5/12 (35.7\%) from serum and 17/26 (65.8\%) from whole blood samples. All PCR positive samples was IgG-positive except two samples; one IgM-positive and one IgG and IgMpositive serum samples from women who have had spontaneous abortions. Table 2 summarizes serological and corresponding PCR results.

Figure 2a shows the PCR products resulted from the first round PCR and the semi-nested PCR which were $999 \mathrm{bp}$ and $619 \mathrm{bp}$, respectively. Semi-nested PCR was done for PCR products which gave faint bands in the first round. By this PCR we confirmed five more samples. These included two leukaemia and two positive HIV whole blood samples, and one aborted woman serum sample (Fig. $2 \mathrm{~b}$ ).

Table 2 Serological and corresponding PCR results

\begin{tabular}{|c|c|c|c|c|c|c|c|}
\hline \multirow[t]{2}{*}{ Groups } & \multicolumn{4}{|l|}{ Serology Results } & \multicolumn{3}{|c|}{ PCR and semi-nested PCR Results } \\
\hline & No. of Samples & $\lg G$ & $\operatorname{lgG\& lgM}$ & $\overline{\lg M}$ & No. of Samples & Serum & Whole Blood \\
\hline Women who have had spontaneous abortions & 140 & 36 & 12 & 6 & 16 & $2 / 6$ & $6 / 10$ \\
\hline HIV & 26 & 23 & - & - & 15 & $3 / 6$ & $6 / 9$ \\
\hline Leukaemia and lymphoma patients & 9 & 6 & - & - & 6 & - & $4 / 6$ \\
\hline Ocular infection & 2 & 1 & - & - & 1 & - & $1 / 1$ \\
\hline Total & 177 & 66 & 12 & 6 & 38 & $5 / 12$ & $17 / 26$ \\
\hline
\end{tabular}




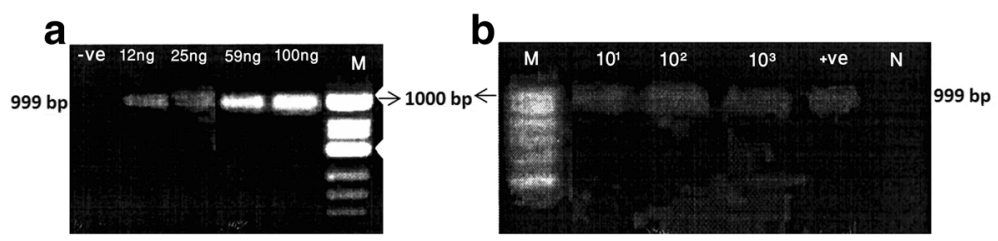

Fig. 1 a: PCR amplification performed with various DNA concentrations. The quantity of DNA is shown above each lane, minimum amount detected was 12 ng. ve + =positive control. b: PCR for detection of T. gondii DNA in whole blood samples spiked with $10^{1}, 10^{2}$ and $10^{3}$ tachyzoites. Lane $\mathrm{N}=$ whole blood without tachyzoites, $+v e=$ positive control (DNA extracted from pure tachyzoites). The bands were quantified by using the software ImageJ. The percentage of the area under the curve was $10^{1}=12 \%, 10^{2}=25 \%, 10^{3}=30 \%$ and + ve $=33 \%$. -ve = negative control, $M=100-b p$ DNA ladder (BIORON)

\section{Discussion}

PCR has been consistently used to detect DNA of $T$. gondii in various biological samples and has showed higher sensitivity in diagnosis compared to serological tests and culture [25, 47-50]. Moreover, the potential of PCR to diagnose active toxoplasmosis is of great importance for immunocompromised patients and congenital toxoplasmosis particularly when serological techniques failed [51]. Most researchers have used the B1 and SAG1 for detection of Toxoplasma [43, 52-54]. However, a nested PCR assay based on the polymorphic SAG2 locus was developed [43, 44]. SAG2 gene encodes two separate forms of the surface tachyzoite protein p22 that are recognized by strain-specific monoclonal antibodies and allow for adequate genotyping of $T$. gondii $[44,55]$. The genetic analysis based on this gene requires a small amount of DNA, thus allowing it to be amplified directly from clinical samples [44].

For the very first time in Libya, we developed a sensitive and specific PCR of SAG2 gene to detect T. gondii in clinical samples. Positive results were detectable after the first round of PCR. However, semi-nested PCR was essential to confirm specificity of first round products with faint band intensity. This investigation was based on the combined results of positive serological tests for IgG and/or IgM antibodies, which confirms $T$. gondii DNA in whole blood and serum samples among different patients (women with history of repeated abortion, positive HIV patients, leukaemia and congenital cases).

As for all parasitic diseases, the PCR diagnosis of toxoplasmosis is not standardized [41]. Therefore, we adjusted PCR conditions to give optimum sensitivity and specificity without appearance of artifacts. The use of this assay allowed for a highly sensitive detection of less than 10 tachyzoites of $T$. gondii DNA and a minimum concentration of $12 \mathrm{ng} / \mathrm{ml}$. The detection limit of the conventional PCR varied depending on the amounts of pure $T$. gondii tachyzoites that were mixed with whole blood. A decreased performance of conventional PCR may be expected when exceeding certain amount of non-specific DNA in a reaction volume. Interestingly, the conventional single step PCR assay targeting SAG2 in the first round was successful as in the previous studies used a nested PCR
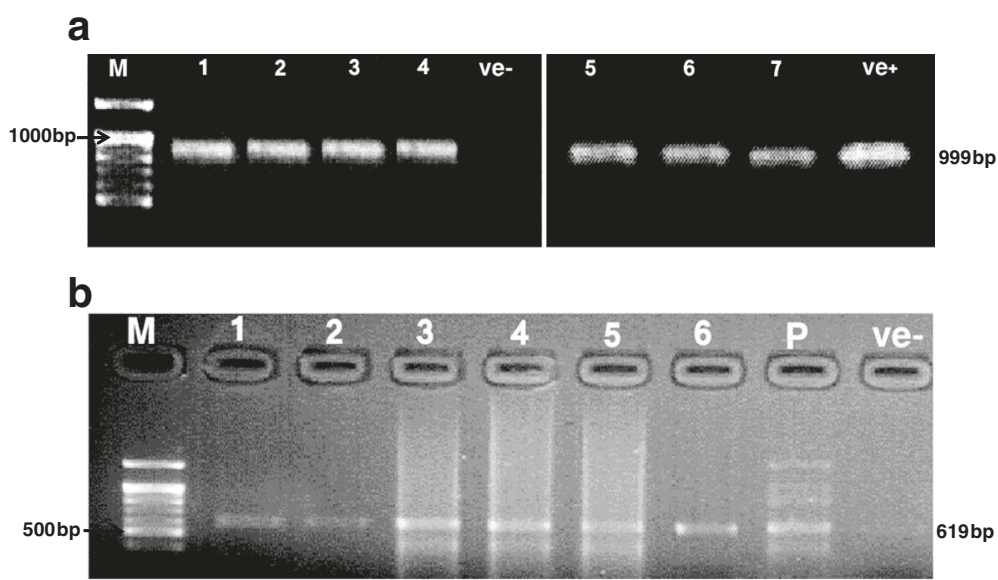

Fig. 2 a: PCR amplification of T. gondii SAG2 gene in $1.7 \%$ agarose gel. Lane 1 and $2=$ positive HIV whole blood samples. Lanes 3 and $4=$ leukaemia whole blood samples. Lane 5 and $6=$ aborted woman serum and whole blood respectively. Lane $7=$ patient with ocular infection. Ve $+=$ positive control (RH strain). b: Semi-nested PCR amplification of T. gondii SAG2 gene for samples with faint band in the first PCR run. Lanes; 1 and $2=$ positive HIV whole blood samples. Lanes 3 and 5 = leukaemia whole blood samples. Lane 4; aborted woman serum sample. Lane $6=$ seronegative toxoplasmosis aborted woman whole blood sample. Lane $P=$ positive control (RH strain). Ve- = is negative control (blanked water), M=100 bp DNA Ladder (BIORON) 
protocol targeting the same gene [44, 55]. Moreover, the semi-nested PCR system may increase the sensitivity due to its dilution effect between the first and the second round of PCR if inhibitory factors are present. However, the risk of carry-over contamination between first and second rounds of PCR should be considered to avoid false positive results which may make this approach less suitable in the routine laboratory tests.

In the present study, discrepancies between serology and PCR results were detected since 22/38 (57.9 \%) of tested seropositive samples were PCR positive. Possible explanation is that the clearance time for Toxoplasma DNA from the patient's blood was estimated to be 5.5-13 weeks [56]. Based on this, the presence of Toxoplasma DNA in the peripheral blood probably indicates a recent infection or apparent parasitaemia that is likely to be clinically significant. Conversely, a small number of parasites might have been released from tissue into the blood at a subclinical level and their presence can be detected only by PCR [57].

In this study, $T$. gondii DNA was detected only in $2 / 5$ IgM positive women who have had spontaneous abortions and 3/11 women showed no evidence of infection by PCR, though IgG antibodies were detected. This can be attributed to the presence of a long standing immunity to toxoplasmosis or cross-reactive antibodies $[58,59]$ and confirm the sensitivity and specificity of PCR analysis for detecting recent infection in early pregnancy [60]. This is in agreement with previous reports that PCR is recommended over serologic techniques for diagnosis of toxoplasmosis [61-63].

Toxoplasma DNA was detected in one of two children clinically diagnosed with ocular infection. The first child was both PCR and seropositive at 4 months of age. The second child was both PCR and seronegative at 8 years of age. This indicated that our PCR assay may be used to confirm ocular toxoplasmosis and to differentiate it from other ocular diseases. Our results are in agreement with previously published reports [64].

The emergence of human immunodeficiency virus HIV in Libya has increased the need for more sensitive and reliable diagnostic methods to diagnose opportunistic infections like toxoplasmosis. Latent $T$. gondii infection in $30-50 \%$ of HIV patients have a high risk of progressing to toxoplasmic encephalitis $[65,66]$. In our study, the T.gondii DNA was detected in $(60 \%)$ of the seropositive toxoplasmosis HIV/AIDS patients with CD4 count less than 100 cells/ $\mu l$. Moreover, the average CD8 count was significantly higher for patients who had negative PCR result (data not shown). Serological tests are limited with delayed or impaired production of antibodies in immunocompromised patients. Hence, PCR approaches are superior for diagnosing such cases.

\section{Conclusion}

Diagnosis of $T$. gondii infection in Libya is based on serological detection of specific anti- Toxoplasma immunoglobulin, which has varied sensitivity and specificity, may fail to detect infection especially in immunocompromised patients. For the first time in Libya, we established and optimized semi-nested PCR of SAG2 gene, which is a reliable diagnostic technique with adequate sensitivity and specificity when used to detect $T$. gondii DNA in different clinical settings. The developed PCR method was able to detect as little as $12 \mathrm{ng} / \mu \mathrm{L}$ of $T$. gondii DNA and was useful to diagnose the disease in women who have had spontaneous abortions, HIV-positive patients, patients with leukemia and lymphoma, and infants with ocular infection.

\section{Ethics approval and consent to participate}

All aspects of the study were revised and approved by the ethics committee of the Libyan National Centre for Disease and Control. Informed written consent was obtained from all participants or their parents/guardians.

\section{Consent for publication \\ Not applicable.}

\section{Availability of data and materials}

All the data is contained within the manuscript.

\section{Abbreviations}

ELISA: enzyme-linked immunosorbent assay; Ig: immunoglobulin; PCR: polymerase chain reaction; SAG2: the surface antigen gene 2 .

\section{Competing interests}

The authors declare that they have no competing interests.

\section{Authors' contributions}

This work was accomplished by the contribution of all authors: AG and AAmro conceived and designed the study and experiments. EE, ME, HD contributed to sampling and technical experiments and coordination. AAbudher, NN, and HB contributed reagents/materials/analysis tools. AAmro and AG wrote the manuscript. All authors have revised and approved the manuscript.

\section{Acknowledgements}

We would like to thank the Genetic Laboratory at Bio- technologies Researches Center for providing spaces and machines. We are thankful for the National

Center for Disease Control, Tripoli, Libya for supporting us with chemicals and consumables.

\section{Funding}

The study was carried out in the Genetic Laboratory at Bio- technologies Researches Center which provided spaces and machines. Financial supported for chemicals and consumables was provided by National Center for Disease Control, Tripoli, Libya. These institutions had no role in the design of the study and collection, analysis, and interpretation of data and in writing the manuscript.

\section{Author details}

${ }^{1}$ Faculty of Medical Technology Pathology Department, University of Tripoli, Tripoli, Libya. ${ }^{2}$ Faculty of Pharmacy, Al-Quds University, Main Campus, Abu Dis, P.O. Box 5100, Jerusalem, Palestine. ${ }^{3}$ Medical Laboratory Department, Immunology Unit, Tripoli Central Hospital, Tripoli, Libya. ${ }^{4}$ Faculty of Medicine, Dermatology Department, University of Tripoli, Tripoli, Libya. ${ }^{5}$ Scientific College - Sabrata, Zoology Department, University of Zawia, Zawia, Libya. 
${ }^{6}$ Laboratoire de Parasitologie-Mycologie à la Faculté de Pharmacie, Monastir, Tunisia. ${ }^{7}$ Genetic Laboratory at Bio- technologies Researches Centre, Tripoli, Libya. ${ }^{8}$ Libyan National Centre for Disease Control, Tripoli, Libya.

\section{Received: 28 September 2015 Accepted: 31 March 2016} Published online: 16 April 2016

\section{References}

1. Hill DE, Chirukandoth S, Dubey JP. Biology and epidemiology of Toxoplasma gondii in man and animals. Anim Health Res Rev. 2005;6(1):41-61.

2. Hill DE, Dubey JP. Toxoplasma gondii prevalence in farm animals in the United States. Int J Parasitol. 2013;43(2):107-13.

3. Dubey JP, Jones JL. Toxoplasma gondii infection in humans and animals in the United States. Int J Parasitol. 2008;38(11):1257-78.

4. Weiss LM, Dubey JP. Toxoplasmosis: A history of clinical observations. Int J Parasitol. 2009;39(8):895-901.

5. Montoya JG, Remington JS. Management of Toxoplasma gondii infection during pregnancy. Clin Infect Dis. 2008;47(4):554-66.

6. Torgerson PR, Mastroiacovo P. The global burden of congenital toxoplasmosis: a systematic review. Bull World Health Organ. 2013:91(7):501-8.

7. Havelaar AH, Kemmeren JM, Kortbeek LM. Disease burden of congenital toxoplasmosis. Clin Infect Dis. 2007:44(11):1467-74.

8. Passos LN, Araujo Filho OF, Andrade Junior HF. Toxoplasma encephalitis in AIDS patients in Sao Paulo during 1988 and 1991. A comparative retrospective analysis. Rev Inst Med Trop Sao Paulo. 2000;42(3):141-5.

9. Luft BJ, Hafner R, Korzun AH, Leport C, Antoniskis D, Bosler EM, Bourland DD, 3rd, Uttamchandani R, Fuhrer J, Jacobson J. Toxoplasmic encephalitis in patients with the acquired immunodeficiency syndrome. Members of the ACTG 077p/ANRS 009 Study Team. N Engl J Med. 1993;329(14):995-1000.

10. Wong B, Gold JW, Brown AE, Lange M, Fried R, Grieco M, Mildvan D, Giron J, Tapper ML, Lerner CW. Central-nervous-system toxoplasmosis in homosexual men and parenteral drug abusers. Ann Intern Med. 1984:100(1):36-42

11. Israelski DM, Chmiel JS, Poggensee L, Phair JP, Remington JS. Prevalence of Toxoplasma infection in a cohort of homosexual men at risk of AIDS and toxoplasmic encephalitis. J Acquir Immune Defic Syndr. 1993;6(4):414-8.

12. Maschke M, Kastrup O, Esser S, Ross B, Hengge U, Hufnagel A. Incidence and prevalence of neurological disorders associated with HIV since the introduction of highly active antiretroviral therapy (HAART). J Neurol Neurosurg Psychiatry. 2000;69(3):376-80

13. Porter SB, Sande MA. Toxoplasmosis of the central nervous system in the acquired immunodeficiency syndrome. N Engl J Med. 1992;327(23):1643-8.

14. Pappas G, Roussos N, Falagas ME. Toxoplasmosis snapshots: global status of Toxoplasma gondii seroprevalence and implications for pregnancy and congenital toxoplasmosis. Int J Parasitol. 2009;39(12):1385-94.

15. Mousa DA, Mohammad MA, Toboli AB. Toxoplasma gondii infection in pregnant women with previous adverse pregnancy outcom. Med J Islamic World Acad Sci. 2011:19(2):95-102.

16. Kassem HH, Morsy TA. The prevalence of anti-Toxoplasma antibodies among pregnant women in Benghazi, (S.P.L.A.J.) Libya. J Egypt Soc Parasitol. 1991;21(1):69-74

17. Magrhi S, Abudher A, Guma N, Hagrasi H, Mohammed S, Musbah M, Ali M, Abeed S. Toxoplasmosis and Pregnancy outcome, Second national Biotechnology, Conference proceeding Book. 2003. p. 435-42.

18. Setta AM, Yamani RH. Prevalence of Toxoplasmosis in non-pregnant women in Tripoli, Libya. Egypt J Hosp Med. 2008:31:198-202.

19. Khader MA, El Nageh MM. Serological Survey for Toxoplasmosis in Tripoli, S. P.L.A.J. (Libya). Trans R Soc Trop Med Hyg. 1987:81(5):761-3.

20. Gashout A, Lazrag T, Gashout H, Swedan T. Qualtitive assessement of risk for spotaneous abortion associated with toxoplasma and rubella: immunity appraisal. Libyan J Infec Dis. 2008;2(1):52-6.

21. Alkhunfas SR. Toxoplasmosis in Newborn Babies in AL-Jala Maternity Hospital, Tripoli - Libya, Master thesis, Biology department, Academy of graduate study -Libya. 2008. p. 45-6.

22. Filisetti D, Gorcii M, Pernot-Marino E, Villard O, Candolfi E. Diagnosis of congenital toxoplasmosis: comparison of targets for detection of Toxoplasma gondii by PCR. J Clin Microbiol. 2003:41(10):4826-8.

23. Costa JM, Ernault P, Gautier E, Bretagne S. Prenatal diagnosis of congenital toxoplasmosis by duplex real-time PCR using fluorescence resonance energy transfer hybridization probes. Prenat Diagn. 2001;21(2):85-8.
24. Romand S, Wallon M, Franck J, Thulliez P, Peyron F, Dumon H. Prenatal diagnosis using polymerase chain reaction on amniotic fluid for congenital toxoplasmosis. Obstet Gynecol. 2001;97(2):296-300.

25. Olariu TR, Remington JS, Montoya JG. Polymerase chain reaction in cerebrospinal fluid for the diagnosis of congenital toxoplasmosis. Pediatr Infect Dis J. 2014;33(6):566-70.

26. Rasti S, Behrashi M, Kazemi B, Fatahian A, Mousavi G, Namakchian M. Diagnosis of congenital toxoplasmosis by polymerase chain reaction. Indian J Med Microbiol. 2012;30(2):251

27. Sterkers Y, Ribot J, Albaba S, Issert E, Bastien P, Pratlong F. Diagnosis of congenital toxoplasmosis by polymerase chain reaction on neonatal peripheral blood. Diagn Microbiol Infect Dis. 2011;71(2):174-6

28. Abdul-Ghani R. Polymerase chain reaction in the diagnosis of congenital toxoplasmosis: more than two decades of development and evaluation. Parasitol Res. 2011:108(3):505-12.

29. Sterkers Y, Pratlong F, Albaba S, Loubersac J, Picot MC, Pretet $V$, Issert E, Boulot $P$, Bastien P. Novel interpretation of molecular diagnosis of congenital toxoplasmosis according to gestational age at the time of maternal infection. J Clin Microbiol. 2012:50(12):3944-51.

30. Liu Q, Wang ZD, Huang SY, Zhu XQ. Diagnosis of toxoplasmosis and typing of Toxoplasma gondii. Parasites Vectors. 2015;8:292.

31. Okubo Y, Shinozaki M, Yoshizawa S, Nakayama H, Wakayama M, Hatori T, Mituda A, Hirano T, Shimodaira K, Yuzhu Z. Diagnosis of systemic toxoplasmosis with HIV infection using DNA extracted from paraffin-embedded tissue for polymerase chain reaction: a case report. J Med Case Rep. 2010;4:265.

32. Julander I, Martin C, Lappalainen M, Guy E, Isberg B, Evengard B. Polymerase chain reaction for diagnosis of cerebral toxoplasmosis in cerebrospinal fluid in HIV-positive patients. Scand J Infect Dis. 2001;33(7):538-41.

33. Sugita S, Ogawa M, Inoue S, Shimizu N, Mochizuki M. Diagnosis of ocular toxoplasmosis by two polymerase chain reaction (PCR) examinations: qualitative multiplex and quantitative real-time. Jpn J Ophthalmol. 2011:55(5):495-501.

34. Fekkar A, Bodaghi B, Touafek F, Le Hoang P, Mazier D, Paris L. Comparison of immunoblotting, calculation of the Goldmann-Witmer coefficient, and real-time PCR using aqueous humor samples for diagnosis of ocular toxoplasmosis. J Clin Microbiol. 2008:46(6):1965-7.

35. Simon A, Labalette P, Ordinaire I, Frealle E, Dei-Cas E, Camus D, Delhaes L. Use of fluorescence resonance energy transfer hybridization probes to evaluate quantitative real-time PCR for diagnosis of ocular toxoplasmosis. J Clin Microbiol. 2004;42(8):3681-5.

36. Liesenfeld O, Press C, Flanders R, Ramirez R, Remington JS. Study of Abbott Toxo IMx system for detection of immunoglobulin $\mathrm{G}$ and immunoglobulin M toxoplasma antibodies: value of confirmatory testing for diagnosis of acute toxoplasmosis. J Clin Microbiol. 1996;34(10):2526-30.

37. Shaapan RM, El-Nawawi FA, Tawfik MA. Sensitivity and specificity of various serological tests for the detection of Toxoplasma gondii infection in naturally infected sheep. Vet Parasitol. 2008;153(3-4):359-62.

38. Luft BJ, Remington JS. Toxoplasmic encephalitis in AIDS. Clin Infect Dis. 1992:15(2):211-22

39. Derouin F, Leport C, Pueyo S, Morlat P, Letrillart B, Chene G, Ecobichon JL, Luft B, Aubertin J, Hafner R. Predictive value of Toxoplasma gondii antibody titres on the occurrence of toxoplasmic encephalitis in HIV-infected patients. ANRS 005/ACTG 154 Trial Group. AIDS. 1996:10(13):1521-7.

40. Mechain B, Garin YJ, Robert-Gangneux F, Dupouy-Camet J, Derouin F. Lack of utility of specific immunoglobulin $\mathrm{G}$ antibody avidity for serodiagnosis of reactivated toxoplasmosis in immunocompromised patients. Clin Diagn Lab Immunol. 2000;7(4):703-5.

41. Reischl U, Bretagne S, Kruger D, Ernault P, Costa JM. Comparison of two DNA targets for the diagnosis of Toxoplasmosis by real-time PCR using fluorescence resonance energy transfer hybridization probes. BMC Infect Dis. 2003;3:7.

42. Parmley SF, Gross U, Sucharczuk A, Windeck T, Sgarlato GD, Remington JS Two alleles of the gene encoding surface antigen P22 in 25 strains of Toxoplasma gondii. J Parasitol. 1994;80(2):293-301.

43. Howe DK, Sibley LD. Toxoplasma gondii comprises three clonal lineages: correlation of parasite genotype with human disease. J Infect Dis. 1995:172(6):1561-6.

44. Howe DK, Honore S, Derouin F, Sibley LD. Determination of genotypes of Toxoplasma gondii strains isolated from patients with toxoplasmosis. J Clin Microbiol. 1997;35(6):1411-4.

45. Joseph P, Calderon MM, Gilman RH, Quispe ML, Cok J, Ticona E, Chavez V, Jimenez JA, Chang MC, Lopez MJ. Optimization and evaluation of a PCR 
assay for detecting toxoplasmic encephalitis in patients with AIDS. J Clin Microbiol. 2002;40(12):4499-503.

46. Prince JB, Auer KL, Huskinson J, Parmley SF, Araujo FG, Remington JS. Cloning, expression, and CDNA sequence of surface antigen P22 from Toxoplasma gondii. Mol Biochem Parasitol. 1990;43(1):97-106.

47. Burg JL, Grover CM, Pouletty P, Boothroyd JC. Direct and sensitive detection of a pathogenic protozoan, Toxoplasma gondii, by polymerase chain reaction. J Clin Microbiol. 1989;27(8):1787-92.

48. Cermakova Z, Ryskova O, Pliskova L. Polymerase chain reaction for detection of Toxoplasma gondii in human biological samples. Folia Microbiol. 2005;50(4):341-4.

49. Murat JB, Hidalgo HF, Brenier-Pinchart MP, Pelloux H. Human toxoplasmosis: which biological diagnostic tests are best suited to which clinical situations? Expert Rev Anti-Infect Ther. 2013;11(9):943-56.

50. Dupouy-Camet J, de Souza SL, Maslo C, Paugam A, Saimot AG, Benarous R, Tourte-Schaefer C, Derouin F. Detection of Toxoplasma gondii in venous blood from AIDS patients by polymerase chain reaction. J Clin Microbiol. 1993;31(7):1866-9.

51. Ashburn D, Joss AW, Pennington TH, Ho-Yen DO. Do IgA, lgE, and $\lg G$ avidity tests have any value in the diagnosis of toxoplasma infection in pregnancy? J Clin Pathol. 1998;51(4):312-5.

52. Weiss JB. DNA probes and PCR for diagnosis of parasitic infections. Clin Microbiol Rev. 1995;8(1):113-30.

53. Sibley LD, Boothroyd JC. Virulent strains of Toxoplasma gondii comprise a single clonal lineage. Nature. 1992;359(6390):82-5.

54. Wang $Y$, Yin $\mathrm{H}$. Research progress on surface antigen 1 (SAG1) of Toxoplasma gondii. Parasites Vectors. 2014;7:180.

55. Fuentes I, Rubio JM, Ramirez C, Alvar J. Genotypic characterization of Toxoplasma gondii strains associated with human toxoplasmosis in Spain: direct analysis from clinical samples. J Clin Microbiol. 2001;39(4):1566-70.

56. Guy EC, Joynson DH. Potential of the polymerase chain reaction in the diagnosis of active Toxoplasma infection by detection of parasite in blood. J Infect Dis. 1995;172(1):319-22

57. Garweg J, Boehnke M, Koerner F. Restricted applicability of the polymerase chain reaction for the diagnosis of ocular toxoplasmosis. Ger J Ophthalmol. 1996;5(2):104-8,

58. Remington JS, Miller MJ, Brownlee I. IgM antibodies in acute toxoplasmosis. I. Diagnostic significance in congenital cases and a method for their rapid demonstration. Pediatrics. 1968:41(6):1082-91.

59. Remington JS, Miller MJ, Brownlee I. IgM antibodies in acute toxoplasmosis. II. Prevalence and significance in acquired cases. J Lab Clin Med. 1968;71(5):855-66.

60. Pelloux H, Guy E, Angelici MC, Aspock H, Bessieres MH, Blatz R, Del Pezzo M, Girault V, Gratzl R, Holberg-Petersen M. A second European collaborative study on polymerase chain reaction for Toxoplasma gondii, involving 15 teams. FEMS Microbiol Lett. 1998;165(2):231-7.

61. Wilson M, Remington JS, Clavet C, Varney G, Press C, Ware D. Evaluation of six commercial kits for detection of human immunoglobulin $\mathrm{M}$ antibodies to Toxoplasma gondii. The FDA Toxoplasmosis Ad Hoc Working Group. J Clin Microbiol. 1997;35(12):3112-5.

62. Slawska H, Czuba B, Gola J, Mazurek U, Wloch A, Wilczok T, Kaminski K. Diagnostic difficulties of Toxoplasma gondii infection in pregnant women. Is it possible to explain doubts by polymerase chain reaction? Ginekol Pol. 2005;76(7):536-42.

63. Nimri L, Pelloux H, Elkhatib L. Detection of Toxoplasma gondii DNA and specific antibodies in high-risk pregnant women. AmJTrop Med Hyg. 2004;71(6):831-5.

64. Garweg JG, de Groot-Mijnes JD, Montoya JG. Diagnostic approach to ocular toxoplasmosis. Ocul Immunol Inflamm. 2011;19(4):255-61.

65. Khalifa K-S, Roth A, Roth B, Arasteh KN, Janitschke K. Value of PCR for evaluating occurrence of parasitemia in immunocompromised patients with cerebral and extracerebral toxoplasmosis. J Clin Microbiol. 1994;32(11):2813-9.

66. Alfonso Y, Fraga J, Fonseca C, Jimenez N, Pinillos T, Dorta-Contreras AJ, Cox R, Capo V, Pomier O, Bandera F. Molecular diagnosis of Toxoplasma gondii infection in cerebrospinal fluid from AIDS patients. Cerebrospinal Fluid Res. 2009;6:2.

\section{Submit your next manuscript to BioMed Central and we will help you at every step:}

- We accept pre-submission inquiries

- Our selector tool helps you to find the most relevant journal

- We provide round the clock customer support

- Convenient online submission

- Thorough peer review

- Inclusion in PubMed and all major indexing services

- Maximum visibility for your research

Submit your manuscript at www.biomedcentral.com/submit
Biomed Central 